\title{
Aspects of coyote predation on Angora Goats
}

\author{
LAMAR A. WINDBERG, FREDERICK F. KNOWLTON, STEVEN M. EBBERT, AND BRIAN T. KELLY
}

Authors are wildlife biologists, USDA-APHIS, Denver Wildlife Research Center, Utah State University, Logan, Ut. 84322-5295; current address for Ebbert: U.S. Fish and Wildlife Service, P.O. Box 1938, Homer, Ala. 99603; current address for Kelly: Hill's Pet Nutrition, Inc., Science and Technology Center, P.O. Box 1658, Topeka, Kans. 66601-1658.

\begin{abstract}
A study to assess characteristics of coyotes (Canis latrans Say) that attack livestock was conducted in southern New Mexico. During 4-16 April 1991, 38 Angora does (Capra hircus L.) and their 34 offspring (kids) were exposed to coyote predation in 3 small experimental free-ranging flocks on the study area. One doe and 14 kids were killed by predators, including at least 12 cases of coyote predation. Coyotes selectively preyed on the smaller kids, and on goats in relatively small groups. Remains of 11 kids killed by predators were cached within the core areas of territorial coyotes. Six of 8 territorial coyotes and 5 of 9 transients (nonterritorial coyotes), with ranges that overlapped the distribution of flocks, consumed goats.
\end{abstract}

Key Words: Canis latrans, food cache, predation management

A contemporary goal in predation management is selective control of specific animals responsible for predatory attacks. However, a disputed question is whether episodes of predation on livestock are attributable to all coyotes (Canis latrans Say), or only a few individuals within populations (Wagner 1988). Published information about characteristics of depredating individuals is limited to observations of captive coyotes (Connolly et al. 1976), anecdotal accounts (Young and Jackson 1951), and sparse data from tangential studies (Althoff and Gipson 1981, Todd 1985, Gese and Grothe 1995).

Analyses of relative vulnerability to trapping indicate that there are significant biases toward capture of transient and younger coyotes in populations (Windberg and Knowlton 1990). The effect of these biases on management efforts to selectively target coyotes that prey on livestock is unknown. Also, an assumption that coyotes usually prey on livestock while foraging within their familiar ranges has not been validated. The locations of predatory attacks on livestock may have implications for targeting depre-

\footnotetext{
The authors thank Kris Havstad, Research Leader, USDA-ARS, for supporting this research on the Jornada Experimental Range, and Dick Dunlap and Clyde Yarbrough for their assistance during the study. We are grateful to Kevin Bruce, Richard Burns, Gary Dasch, Gary Duff, Mike Jaeger, John McConnell, Jr., Stan Olmstead, Joe Rhoades, Charles Stoddart, and Doris Zemlicka for field assistance. The manuscript was reviewed by Richard Burns and Mike Fall.

The protocol for this study was approved by the Institutional Animal Care and Use Committee (Denver Wildlife Research Center). Identification of specific products or services does not imply endorsement or recommendation by the USDA over similar companies or products not mentioned.

Manuscript accepted 11 Aug. 1996.
}

dating individuals because coyotes have relatively low vulnerability to capture within their ranges (Windberg and Knowlton 1990).

Our objectives were to describe the age, sex, and territorial classes of coyotes that attack free-ranging Angora goats (Capra hircus L.), the location of successful attacks (kills) on goats by coyotes in relation to coyote territories, and any discernible patterns of predation on goats.

\section{Methods}

The $75 \mathrm{~km}^{2}$ study area was located on the northern portion of the USDA-ARS Jornada Experimental Range (JER), $40 \mathrm{~km}$ north of Las Cruces, Dona Ana County, New Mexico $\left(32^{\circ} 40^{\prime} \mathrm{N}\right.$ $106^{\circ} 44^{\prime} \mathrm{W}$, elev. $\left.1,400 \mathrm{~m}\right)$. The JER $\left(783 \mathrm{~km}^{2}\right)$ is used primarily for grazing by cattle, although experimental flocks of sheep (Ovis aries L.) were located in pastures $3 \mathrm{~km}$ south of the study area. The JER is characterized by basin topography representative of the northern Chihuahuan desert (Hennessy et al. 1983). The climate is arid, with mean annual precipitation of $231 \mathrm{~mm}$ concentrated in late-summer (Hennessy et al. 1983). Mesquite (Prosopis glandulosa) is the predominant woody species and large dunefields have formed on the sandy soils (Buffington and Herbel 1965). Rogers (1965) found that lagomorphs and rodents were primary prey of coyotes in the region during winter-spring 1964-1965, and our cursory examination of coyote feces indicated that they were the staple prey during this study.

Based on similar rates of coyote predation on sheep and goats during preliminary trials we conducted in 1988-1989, the more manageable Angora goats were selected as the representative experimental livestock for this study. The goats were purchased locally and were adapted to foraging in range conditions comparable with those on the study area. Most does were near the end of their reproductive lives ( $84 \%$ were $\geq 4$ years of age based on replacement pattern of incisor teeth). The kids were 1-3 weeks of age, except for 2 individuals which were 4-6 weeks old. The goats were inspected and certified free of diseases by the New Mexico Livestock Board at time of purchase. Immediately prior to transport to the study area on 26 March 1991, all goats were administered an antibiotic (ceftiofur sodium) (Naxcel, The Upjohn Co., Kalamazoo, Mich.) to prevent shipping-fever and general respiratory infection. On 27 March, all goats were examined to record their general health and physical condition, marked with colored and numbered plastic eartags, and administered iver- 
mectin (Ivomec, MSD Agvet, Rahway, N.J.) for broad-spectrum therapeutic treatment of internal and external parasites. Second and third doses of antibiotic were administered to all goats on 27-28 March; they received a second treatment with ivermectin on 6-7 April. On 1 April, the goats were examined for symptoms of diseases by a veterinarian. Ten kids diagnosed with contagious ecthyma (soremouth disease) were excluded from the study. Three flocks of goats (Table 1) were confined in enclosures on the study area for 3-5 days to establish social bonds prior to release.

One day before release of flocks on the study area, a Physiologic Marking Collar (PMC) (Connolly 1990) was mounted on each goat to identify coyotes that attacked them. Large (60 $\mathrm{ml}$ ) and small $(30 \mathrm{ml})$ PMCs contained radioisotopes $(30 \mu \mathrm{Ci}$ of Cesium-134 and $60 \mu \mathrm{Ci}$ of Zinc-65, respectively) in a dyed (1\% tartrazine, Burns and Savarie 1989) water solution. The concentrations of radioisotopes in PMCs were calculated to provide physiologic marks for $\geq 6$ months based on quantities of solution ingested and absorbed during trials with captive coyotes (Knowlton and Ebbert 1991) and the physical and biological halflives of the radioisotopes. Each PMC had a radio-transmitter with a 1-hour inactivity (mortality) sensor affixed to the rear strap. Each goat (does and kids) was also injected intramuscularly with $300 \mathrm{mg}$ of iophenoxic acid for physiological identification of coyotes that consumed goat flesh (Knowlton and S. R. Olmstead, unpub. data). The iophenoxic acid was dissolved in ethyl alcohol (95\%) at a concentration of $188 \mathrm{mg} / \mathrm{ml}$, which yielded a $1.6 \mathrm{ml}$ dose of IA-ethanol solution per goat. Body mass of kids was measured with a spring-balance scale 1 day before release.

After release of flocks from enclosures onto the study area, we attempted to locate all goats twice daily (early-morning and lateafternoon) using radio-tracking procedures. We also attempted to obtain a visual observation of each goat daily to ascertain that they were in satisfactory condition. The location of each group of goats observed visually was plotted on a map of the study area. Dead goats were identified by radio-transmitter signals in mortality mode, and the carcasses were located with radio-telemetry equipment. The carcass and the surrounding area were examined for evidence of the cause of death (Wade and Bowns 1982). Carcasses were typically recovered within 24 hours after death and all remains found were removed from the study area. The radio-transmitter was subsequently placed at an elevated position near the recovery site to estimate its location, as derived by 2 or 3 azimuths from fixed radio-telemetry receiving-stations.

Coyotes were captured with foothold traps and collared with radio-transmitters from 19 February to 21 March 1991. Data for point-estimates of locations of radio-collared coyotes were collected by fixed-station triangulation from 30 March to 29 May and analyzed using program HOME RANGE (Ackerman et al. 1990). Radio-collared coyotes were classified as territorial or transient (nonterritorial) based on the areal distribution of radiotelemetry locations (i.e., exclusive core areas of ranges) as described by Windberg and Knowlton (1988). Thirty-two radiocollared individuals, and 4 unmarked coyotes associated with them, were recovered by shooting during 29-31 May. Their carcasses were necropsied to collect tissue samples of blood, kidney, liver, and skeletal muscle for subsequent analyses for presence of physiologic markers (Knowlton et al. 1988, 1989). The tissues were assayed for radiation energies of Zinc-65 and Cesium-134 using a germanium detector attached to a pulse-height multichannel analyzer. Coyotes that fed on flesh of goats injected with iophenoxic acid were identified by an elevated concentration of protein-bound iodine in blood-serum (Knowlton et al. 1988) from analyses conducted by SmithKline Bio-Science Laboratories (Van Nuys, Calif.). Serum iodine levels $>15 \mu \mathrm{g} / 100 \mathrm{ml}$ were considered positive evidence that coyotes consumed goat flesh (Knowlton and Olmstead, unpub. data).

Ages of coyotes were estimated by patterns of cementum layers in microscopic sections of canine, or first-premolar, teeth prepared by Matson's Laboratory (Milltown, Mont.). Frequency data for predation on goats were analyzed with Fisher's exact tests. Mean mass of kids killed by predators was compared by $t$-test.

\section{Results and Discussion}

Forty one coyotes ( 26 males and 15 females) were marked with radio-collars. This sample comprised a low proportion of younger coyotes as only $7 \%$ were juveniles and $12 \%$ were 2 years old. Thirteen coyotes were classed as territorial and 12 as transients. There were insufficient data for classification of other radio-collared coyotes. Core areas (Ackerman et al. 1990) of 11 coyote territorial ranges were identified in the vicinity of the free-ranging flocks of goats (Fig. 1). We considered radio-collared coyotes to have been exposed to goats if the $85 \%$ harmonic-mean estimate (Ackerman et al. 1990) of their activity areas overlapped the distribution of a flock. Eight territorial and 9 transient coyotes were exposed to goats during the study.

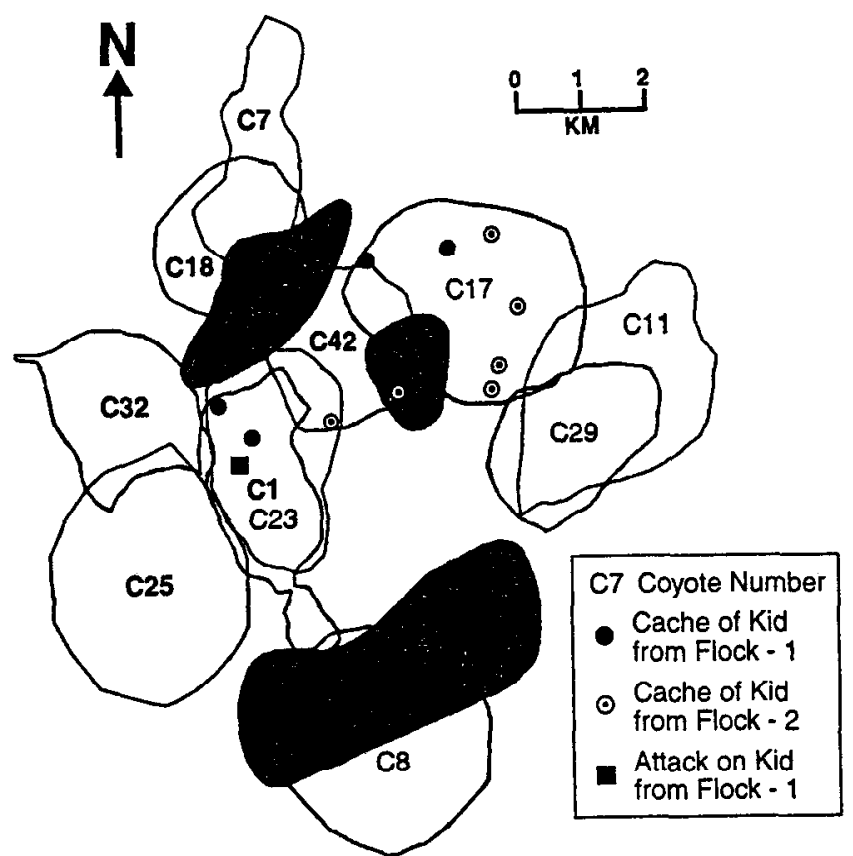

Fig. 1. Distribution of 12 food caches of Angora kids, and 1 site of attack, by coyotes in relation to core areas of coyote territorial ranges. Shaded areas represent minimum observed ranges of 3 flocks of goats (Flock-1 = upper, Flock-2 = middle, Flock-3 = lower). Coyote identification numbers in boldface print indicate individuals that consumed goat. 
The 3 flocks of Angora goats were released on 4-6 April and generally remained within $1 \mathrm{~km}$ of their enclosures for 4-6 days. Because the flocks were reluctant to range from their enclosures to forage, we discontinued providing supplemental food there on 10 April and the flocks immediately began ranging farther away. Extremely strong winds also began on 10 April and continued unabated for 3 successive days resulting in disruption and dispersal of the flocks. We subsequently discontinued exposure of goats to coyote predation on the study area on 16 April.

One doe and 14 kids were killed by predators during 8-15 April (Table 1). Twelve of the mortalities were confirmed as coyote predation based on evidence associated with the carcass (tracks, wounds, food cache). Predation was the cause of death for the other 3 goats and, although the specific predators could not be positively identified, also appeared attributable to coyotes. Four additional goats ( 3 kids and 1 doe) died during the same period but the causes were undetermined because they were recovered outside the study area several days after death.

Table 1. Flock size, exposure time, and predation on Angora goats on the JER study area, April 1991.

\begin{tabular}{|c|c|c|c|c|c|c|}
\hline \multirow{2}{*}{$\begin{array}{l}\text { Flock } \\
\text { number }\end{array}$} & \multicolumn{2}{|c|}{$\begin{array}{l}\text { Initial size } \\
\text { of flocks }\end{array}$} & \multirow{2}{*}{$\begin{array}{l}\text { Period of } \\
\text { exposure to } \\
\text { predation }\end{array}$} & \multicolumn{2}{|c|}{$\begin{array}{c}\text { Days exposure } \\
\text { of goats }\end{array}$} & \multirow{2}{*}{$\begin{array}{c}\text { Goats }^{2} \\
\text { killed by } \\
\text { predators }\end{array}$} \\
\hline & Doe & Kid & & Doe & $\overline{\text { Kid }}$ & \\
\hline & \multicolumn{2}{|c|}{$\ldots$ - (No.) - - } & & \multicolumn{2}{|c|}{$\ldots($ No. $) \ldots$} & $-($ No. $)-$ \\
\hline 1 & 13 & 11 & 6-16 Apr & 91 & 71 & 8 \\
\hline 2 & 12 & 12 & 4-16 Apr. & 120 & 90 & 6 \\
\hline 3 & 13 & 11 & 5-16 Apr. & 137 & 82 & 1 \\
\hline Total & 38 & 34 & 4-16 Apr. & 348 & 243 & 15 \\
\hline
\end{tabular}

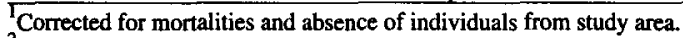

${ }^{2}$ All were kids except for 1 doe from Flock-1.

The cumulative exposure time for goats on the study area was 348 days for does and 243 days for kids (Table 1). Predation loss was notably less for Flock-3 than the other flocks (Table 1). The only predation in Flock-3 occurred when a doe and 2 kids moved $5 \mathrm{~km}$ northeast of their flock. Most predation (12 of 15 cases) occurred after the flocks splintered into smaller groups. In 11 cases, the victim was associated with only $1-4$ other goats on the day prior to the attack. Only 3 cases of predation occurred when goats were in flocks ( $\geq 10$ individuals) during a cumulative exposure of 22 days, whereas 12 goats were killed by predators from smaller groups ( $\leq 7$ individuals) during 25 cumulative days of exposure $(\underline{P}=0.08)$.

At least $41 \%$ of the 34 Angora kids were killed by predators during 12 days of exposure on the study area. This remarkably high rate of predation occurred despite no recent ( $>7$ years) exposure of goats, or sheep, as prey on our study area (R.P. Gibbens, USDA-ARS, JER, pers. com.). Further, the predation occurred before the peak of the pup-rearing season when additional food demands to provision litters might result in increased coyote predation on livestock (Till and Knowlton 1983). Although the coyote population around much of the JER was considered to be lightly exploited by humans (Howard and del Frate 1991), there was no recent history of control, harvest, or other exploitation of coyotes on our study area (C.C. Yarbrough, USDA-ARS, JER, pers. com.). Hence, the immediate and high coyote predation on goats observed during this study is contrary to speculation in the popular press (Milstein 1991, Smith 1993) that unexploited coyote populations pose less risk to livestock. However, most kids killed by coyotes were in atypically small groups instead of larger flocks characteristic of many goat production operations. Guthery and Beasom (1978) also reported that Angora kids were readily killed by naive coyotes in Zavala County, Tex., and that most were killed during their first days of life before joining the flock. This pattern of coyotes selectively preying on goats disassociated from flocks may identify a limitation in the use of guarding animals for livestock protection (Green et al. 1984).

Predation losses of $41 \%$ of kids versus $3 \%$ of does $(P<0.001)$ showed a distinct selection of kids over adults. Mean body mass of 14 kids killed by predators $(\bar{x}=5.8 \mathrm{~kg}, S E=0.3)$ was less $(\mathrm{P}=$ 0.03 ) than mass of 15 kids surviving exposure to predators $(\bar{x}=$ $7.6 \mathrm{~kg}, \mathrm{SE}=0.7)$. Further analysis of predation rates for 3 size classes $(\leq 5.0 \mathrm{~kg}, 5.1-8.9 \mathrm{~kg}, \geq 9.0 \mathrm{~kg})$ of kids revealed a significantly greater $(P<0.01)$ proportion $(0.36$ vs 0.07$)$ of smaller kids $(\leq 5 \mathrm{~kg}$ ) killed by predators whereas a greater proportion $(0.33 \mathrm{vs}$ 0 ) of larger kids ( $\geq 9 \mathrm{~kg}$ ) survived. Thus, coyotes selectively preyed on the smallest goats available during our study. Henne (1977) and Guthery and Beasom (1978) also noted that predators selected the youngest lambs and goats during their studies, although supporting data were not provided.

Of 15 goats killed by predators, remains of their carcasses were located at the site of attack in only 2 cases. Portions of the carcasses of 12 kids and 1 doe were found in food caches made by coyotes. The cached remains of kids ranged from entire carcasses $(n=2)$ to only the head and cape $(n=2)$. Most caches $(n=8)$ were composed of anterior halves of carcasses, including the front legs. We only recovered the cached head of the doe killed by coyotes. Because the radio-transmitters were attached to the PMC strapped around the head, we were able to find caches of the anterior portion of carcasses whereas any additional caches of other portions could not be readily located. The tendency for coyotes to begin feeding on the posterior portion of livestock carcasses (Wade and Bowns 1982) suggests that the remains we located may have been the primary caches. The relationship between the locations of caches and the sites of predatory attacks were undetermined. During a preliminary trial in western Texas in spring 1989, 6 of 11 radio-collared kids and lambs killed by predators were cached, including 2 caches of Angora kids killed by coyotes found 1.4 and $2.1 \mathrm{~km}$ from the location of their flock (Windberg, unpub. data). Our recovery of most remains of goats killed by predators in well-disguised caches provides strong support for the contention of others (Nesse 1974, Guthery and Beasom 1978, Wagner 1988) that many unexplained losses of sheep and goats were attributable to coyote predation even though carcasses were not found.

The only documented site of a coyote attack on a kid within the study area was located near the center of a territorial core area shared by 2 coyotes ( $\mathrm{C} 1$ and $\mathrm{C} 23$ ) (Fig. 1). Twelve caches of kids were located on the study area (Fig. 1). Two caches were in the core areas of the 2 coyotes ( $\mathrm{C} 1$ and $\mathrm{C} 23$ ) in which the kill site was located. Based on analyses for protein-bound iodine in their serum, the 4-year-old male (C1) had consumed goat flesh, whereas the 3-year-old female (C23) had not. Two caches were in the core area of a 3-year-old female (C42), which had consumed goat, and an additional cache was in a portion of her core area 
that partially overlapped the core area of coyote-C1. Six caches were within the core area of a 6-year-old female (C17) that died before recovery, which precluded analysis for iodine residue. The remaining cache was slightly outside the core area, but within the 75\% harmonic-mean estimate of the range of a 2-year-old female (C18), which had consumed goat. A 1-year-old male (C7) which shared part of the core area with coyote-C18 had also consumed goat (Fig. 1). The cached head of the doe was $1 \mathrm{~km}$ north of the area where coyote territorial ranges were delineated. During the period of exposure, Flock-1 and Flock- 2 entered the ranges of 4 coyotes in which caches of carcasses were located (Fig. 1). Flock-3 ranged in the core area of a 4-year-old territorial female (C8) which had not consumed goat (Fig. 1). Some small groups of goats dispersed beyond the ranges of the main flocks, and 2 additional coyotes (C25 and C32) with core areas west of the flocks had also consumed goats.

The relatively small size of most kids made it difficult to maintain the PMCs in the proper position to be punctured during coyote attacks. The PMCs became dislocated (i.e., hanging loosely around neck) on 7 of the 14 kids killed by predators. Although all 14 kids killed by predators had tooth punctures in their neck (predominantly the anterior portion), only 2 of the PMCs were punctured. In contrast, 5 of 7 properly-mounted PMCs on older kids (7-10 weeks of age) were punctured by predators during a preliminary trial in 1989 (Windberg, unpub. data). The PMC on the doe killed by coyotes was punctured. Additionally, the PMC on 1 of 4 goats that died from undetermined causes was punctured. Assays of tissues (liver, kidney, muscle) from 36 coyotes recovered on the area after the study yielded no evidence of radioisotopes to associate them with puncture of PMCs during attacks on goats.

Of the radio-collared coyotes with ranges overlapping the distribution of goat flocks, 6 of 8 territorial individuals and 5 of 9 transients consumed goats. From this sample, we detected no difference $(P=0.62)$ between the proportion of territorial and transient coyotes that consumed Angora goats. There was no difference ( $P=0.99$ ) in the proportion of young (1-2 years) coyotes that consumed goats ( 3 of 11 ) versus those that did not consume goats $(1$ of 6$)$. A greater proportion $(P=0.05)$ of coyotes that consumed goats were males ( 8 of 11 ) compared with coyotes that were exposed to but did not consume goats ( 1 of 6 ). Observations of sheep-attacking behavior among captive coyotes by Connolly et al. (1976) found most sheep killed by males. Gese-and Grothe (1995) observed alpha male coyotes leading 8 of 9 attacks on deer (Odocoileus virginianus) and elk (Cervus elaphus). Also, Young and Jackson (1951) stated that tracks of male coyotes were more evident than those of females at kill sites of lambs, and Todd (1985) noted a trend for diets of male coyotes to include more ungulates than females.

The nature of our data precludes definitive statements directly connecting coyotes that consumed goat flesh to their actual predation on goats. Coyote predation was judged to be the probable cause of 15 goat mortalities during the study. We believe it is reasonable to assume that coyotes which killed goats subsequently consumed a full meal of their flesh. The concentration of proteinbound iodine ranged from 320 to $750 \mu \mathrm{g} / 100 \mathrm{ml}$ in serum of 10 coyotes, which suggested that each consumed a large meal of goat flesh (Knowlton and Olmstead, unpub. data). The mean mass of kids lost to predation $(5.8 \mathrm{~kg}$ ) represented approximately 4 meals for coyotes (Lindsey 1987). We removed about half of the total mass of kid carcasses $<24$ hours after death. Hence, at least 1 additional meal from each predated kid potentially remained available on the study area. This excess flesh from carcasses may have been consumed by coyotes associated with the killing individual, or cached. We had no data to associate the locations of caches of goats with specific coyotes. Foxes (Vulpes vulpes) that made food caches were observed to be the individual that retrieved them (Macdonald 1976) and 4 African wild dogs (Lycaon pictus) retrieved their caches $\leq 1$ day later (Malcolm 1980). Because coyotes that cached unrecovered remains probably retrieved them, we believe it is reasonable to assume that the majority of coyotes which consumed goats during this study were responsible for or involved in their predation.

In 2 cases, we recovered an unmarked male coyote with a radio-collared territorial female (C18 and C32), suggesting that the pairs were territorial associates. Both these males had also consumed goat flesh, suggesting that sharing of carcasses by territorial groups occurred. If so, our data for the proportion of coyotes that consumed goats may be biased toward territorial individuals because transients tend to be primarily solitary (Camenzind 1978, Crabtree 1988). Further, the relative exposure to goats as prey was less for the radio-collared transients than territorial coyotes due to their larger ranges (Windberg and Knowlton 1988). Nevertheless, at least 5 transient coyotes consumed goats. About half of the caches were located along the apparent edges of core areas of coyote territories (Fig. 1). Some of those caches may have been made by transient coyotes because Windberg and Knowlton (1988) found that transients tended to be located in interstices of territories.

\section{Conclusions}

Coyotes began preying on Angora goats almost immediately after they were released on the JER study area during April 1991. Most coyote predation was directed at small disassociated groups of goats $(\leq 7)$ instead of the larger flocks (10-24 goats). Coyote predation during the 12-day period of goat exposure was predominantly on kids, with a preference for smaller kids. We noted a trend for greater consumption of goats by male coyotes, but detected no differences in the propensity of various age or territorial classes of coyotes to consume goats. Therefore, our results suggest that management measures used to protect livestock during periods of exposure of highly vulnerable kids or lambs may be best directed at local coyote populations rather than at particular cohorts or individuals within the population.

\section{Literature Cited}

Ackerman, B.B., F.A. Leban, M.D. Samuel, and E.O. Garton. 1990. User's manual for program HOME RANGE. Second edition. For. Wildl. Range Exp. Sta. Tech. Rep. 15. Univ. of Idaho, Moscow.

Althoff, D.P. and P.S. Gipson. 1981. Coyote family spatial relationships with reference to poultry losses. J. Wildl. Manage. 45:641-649.

Buffington, L.C. and C.H. Herbel. 1965. Vegetational changes on a semi-desert grassland range from 1858 to 1963. Ecol. Monogr. 35:139-164. 
Burns, R.J. and P.J. Savarie. 1989. Persistence of tartrazine in marking sheep wool. Proc. Eastern Wildl. Damage Control Conf. 4:95-100.

Camenzind, F.J. 1978. Behavioral ecology of coyotes on the National Elk Refuge, Jackson, Wyoming, p. 267-294. In: M. Bekoff (ed), Coyotes: biology, behavior, and management. Academic Press, New York, N.Y.

Connolly, G. 1990. The livestock protection collar, p. 89-93. In: G.A. Giusti, R.M. Timm, and R.H. Schmidt (eds), Predator management in north coastal California. Univ. Calif. Hopland Field Sta. Pub. 101, Hopland, Calif.

Connolly, G.E., R.M. Timm, W.E. Howard, and W.M. Longhurst. 1976. Sheep killing behavior of captive coyotes. J. Wildl. Manage. 40:400-407.

Crabtree, R.L. 1988. Sociodemography of an unexploited coyote population. Ph.D. Thesis, Univ. of Idaho, Moscow, Ida.

Gese, E.M. and S. Grothe. 1995. Analysis of coyote predation on deer and elk during winter in Yellowstone National Park, Wyoming. Amer. Midl. Natur. 133:36-43.

Green, J.S., R.A. Woodruff, and T.T. Tueller. 1984. Livestock guarding dogs for predator control: cost, benefits and practicality. Wildl. Soc. Bull. 12:44-50.

Guthery, F.S. and S.L. Beasom. 1978. Effects of predator control on Angora goat survival in south Texas. J. Range Manage. 31:168-173.

Henne, D.R. 1977. Domestic sheep mortality on a western Montana ranch, p. 133-146. In: Phillips, R.L. and C. Jonkel (eds), Proc. 1975 Predator Symp. Mont. For. and Conserv. Exp. Sta., Missoula, Mont.

Hennessy, J.T., R.P. Gibbens, J.M. Tromble, and M. Cardenas. 1983. Vegetation changes from 1935 to 1980 in mesquite dunelands and former grasslands of southern New Mexico. J. Range Manage. 36:370-374.

Howard, V.W., Jr. and G.G. del Frate. 1991. Home ranges and movements of coyotes in the northern Chihuahuan desert. Proc. Great Plains Wildl. Damage Conf. 10:39-49.

Knowlton, F.F. and S.M. Ebbert. 1991. Develop physiologic markers to identify coyotes that kill sheep or goats. Final Rep., Study Protocol QA-090, USDA, Denver WildI. Res. Cent., Denver, Colo. 25p.

Knowlton, F.F., P.J. Savarie, C.E. Wahlgren, and D.J. Hayes. 1988. Retention of physiological marks by coyotes ingesting baits containing iophenoxic acid, mirex, and rhodamine B, p. 141-147. In: S.A. Shumake and R.W. Bullard (eds), Vertebrate pest control and management materials: 5th Vol. ASTM STP 974. Amer. Soc. Testing and Mater. Symp., Philadelphia, Penn.

Knowlton, F.F., L.C. Stoddart, R.L. Crabtree, and J.W. Blatt. 1989. Evaluation of some radioisotopes as marking agents for monitoring bait consumption, p. 52-62. In: K.A. Fagerstone and R.D. Curnow (eds), Vertebrate pest control and management materials: 6th Vol. ASTM STP 1055. Amer. Soc. Testing and Mater. Symp., Philadelphia, Penn.

Macdonald, D.W. 1976. Food caching by red foxes and some other carnivores. Zeitschrift fur Tierpsychologie. 42:170-185.

Lindsey, S. L. 1987. The effect of food availability on the social organization and behavior of captive coyotes (Canis latrans). Ph.D. Thesis, Colorado State Univ., Fort Collins, Colo.

Malcolm, J.R. 1980. Food caching by African wild dogs (Lycaon pictus). J. Mammal. 61:743-744.

Milstein, M. 1991. Yellowstone's top dog. Nat. Parks. 65:25-29.

Nesse, G.E. 1974. Predation and the sheep industry in Glenn County, California. M.S. Thesis, Univ. of California, Davis, Calif.

Rngers, J.G. 1965. Analysis of the coyote population of Dona Ana County, New Mexico. M.S. Thesis, New Mexico State Univ., Las Cruces, N.M.

Smith, C. 1993. Wild ideas: who owns a grizzly bear. Utah Holiday. $5: 40-45$.

Till, J.A. and F.F. Knowlton. 1983. Efficacy of denning in alleviating coyote depredations upon domestic sheep. J. Wildl. Manage. 47:1018-1025.

Todd, A.W. 1985. Demographic and dietary comparisons of forested and farmland coyotes, Canis latrans, populations in Alberta. Can. FieldNat. 99:163-171.

Wade, D.A. and J.E. Bowns. 1982. Procedures for evaluating predation on livestock and wildlife. Tex. Agr. Ext. Serv. Rep. No. B-1429.
Wagner, F.H. 1988. Predator control and the sheep industry. Regina Books, Claremont, Calif.

Windberg, L.A. and F.F. Knowlton. 1988. Management implications of coyote spacing patterns in southern Texas. J. Wildl. Manage. $52: 632-640$.

Windberg, L.A. and F.F. Knowlton. 1990. Relative vulnerability of coyotes to some capture procedures. Wildl. Soc. Bull. 18:282-290.

Young, S.P. and H.H. Jackson, 1951. The clever coyote. Stackpole Books, Harrisburg, Penn. 